\title{
GENETICAL STUDIES IN ACACIAS. I. THE ESTIMATION OF NATURAL CROSSING IN BLACK WATTLE
}

\author{
A. A. MOFFETT
}

Wattle Research Institute, University of Natal

\section{INTRODUCTION}

13.vii. 55

Two closely-related species of Acacias, A. decurrens or green wattle and A. mollissima or black wattle, are grown in the Union of South Africa for tannin production. Green wattle, although generally considered hardier under adverse conditions, does not produce so high a quality of tannin. The small proportion of green wattle previously under cultivation has therefore now been largely replaced by black wattle.

From the genetical point of view, however, green wattle has one marked advantage : the seed ripens some four months after flowering, as opposed to fourteen months in black wattle. Philp and Sherry (1946) therefore chose green wattle for their preliminary work on the degree of natural crossing in wattle and they were able to show that the species was largely cross-pollinated. Because of the close resemblance between the two species, they suggested that black wattle would also prove to be largely cross-pollinated. Selfed progeny from several black wattle trees have now been grown and scored for recessive seedling characters and it has been possible to calculate the approximate amount of natural crossing in many of these trees.

\section{METHODS}

Selfed and natural (open-pollinated) progenies were grown from 26 trees from various parts of the wattle-growing area. The method of bagging followed that of Philp and Sherry (loc. cit.), cellophane bags being used throughout. Bagging was confined to trees near the borders of plantations since the small crowns, inaccessibility, and the high proportion of bags damaged by wind made bagging of more central trees a hazardous and impracticable proposition.

Seeds for sowing were made permeable by removing a small chip of the seedcoat from the distal end. This method of preparing the seed was found to give a higher and more even germination than the more usual treatment with hot water and this factor greatly facilitated the scoring of seedling characters. As far as possible, selfed and open-pollinated progeny were grown from seed collected in the same year, but in some instances additional natural seed collected in the following year was sown.

\section{FERTILITY AND GERMINATION}

The inflorescence is a panicle of some hundreds of globose head each consisting of $35-40$ closely packed flowers. An average-size inflorescence consists of well over 20,000 flowers. Even with open pollination, only a small fraction of these flowers form pods, but it is obvious by inspection that selfed inflorescences produce, on the 
average, fewer pods than open-pollinated inflorescences of the same size.

Since counts of flowers and pods set are not feasible, the number of viable seeds per pod was used as a measure of fertility. Sections of young flower buds showed that the great majority of developing pods had two rows of seven ovules each. In a small percentage only thirteen ovules were counted but in no instance where this occurred

TABLE I

Fertility and germination following self- and open-pollination

\begin{tabular}{|c|c|c|c|c|c|c|c|c|c|}
\hline \multirow{2}{*}{\multicolumn{2}{|c|}{ Tree number }} & \multicolumn{4}{|c|}{ Self-pollinated } & \multicolumn{4}{|c|}{ Open-pollinated } \\
\hline & & $\begin{array}{l}\text { No. of } \\
\text { pods }\end{array}$ & $\begin{array}{c}\text { Mean } \\
\text { per } \\
\text { pod }\end{array}$ & $\begin{array}{c}\text { Seed } \\
\text { set } \\
\text { per cent. }\end{array}$ & $\begin{array}{c}\text { Germin- } \\
\text { ation } \\
\text { per cent. }\end{array}$ & $\begin{array}{l}\text { N. of } \\
\text { pods }\end{array}$ & $\begin{array}{c}\text { Mean } \\
\text { per } \\
\text { pod }\end{array}$ & $\begin{array}{c}\text { Seed } \\
\text { set } \\
\text { per cent. }\end{array}$ & $\begin{array}{l}\text { Germin- } \\
\text { ation } \\
\text { per cent. }\end{array}$ \\
\hline Sweetwaters & $I$ & 203 & 3.03 & $2 I \cdot 7$ & $79 \cdot 1$ & 40 & $5 \cdot 30$ & $38 \cdot 2$ & $89 \cdot 4$ \\
\hline , & 2 & $25^{8}$ & $1 \cdot 08$ & $7 \cdot 7$ & 63.7 & 40 & $4 \cdot 12$ & $29 \cdot 5$ & $62 \cdot 7$ \\
\hline , & 3 & 17 & $2 \cdot 76$ & $19 \cdot 7$ & 90.7 & 40 & $4 \cdot 70$ & $33 \cdot 6$ & $90 \cdot 7$ \\
\hline ", & 4 & 10 & I 00 & $7 \cdot I$ & $85 \cdot 7$ & 40 & $4 \cdot 80$ & $34^{\cdot} \cdot I$ & $85 \cdot 3$ \\
\hline , & 5 & I 5 & $2 \cdot 02$ & $15 \cdot 7$ & $95 \cdot 1$ & 40 & $5 \cdot 60$ & $40 \cdot 3$ & $96 \cdot 0$ \\
\hline & 6 & 42 & I $\cdot 88$ & $13 \cdot 4$ & $95 \cdot 3$ & 40 & $6 \cdot 30$ & $45 \cdot 2$ & $89 \cdot 1$ \\
\hline Yarrow & 46 & 167 & $2 \cdot 10$ & $14 \cdot 7$ & $89 \cdot 8$ & 50 & $7 \cdot 50$ & $53 \cdot 3$ & $9^{1} \cdot 3$ \\
\hline ", & 48 & 37 & $I \cdot 80$ & $12 \cdot 5$ & $64 \cdot 7$ & 50 & $6 \cdot 20$ & $44^{\circ} 0$ & $83 \cdot 4$ \\
\hline , & $5^{2}$ & $4 I$ & $2 \cdot 60$ & $18 \cdot 5$ & $43 \cdot 7$ & 50 & $5 \cdot 20$ & $37 \cdot 6$ & $49 \cdot 2$ \\
\hline ", & 53 & 9 & $2 \cdot 80$ & $19 \cdot 8$ & 84.0 & 50 & $4 \cdot 60$ & $32 \cdot 8$ & $95 \cdot 7$ \\
\hline Mowbray & 66 & 50 & $1 \cdot 72$ & $12 \cdot 3$ & $8 \mathrm{I} \cdot 7$ & 20 & $8 \cdot 15$ & $58 \cdot 2$ & 88.0 \\
\hline , & 67 & & ot recor & led & $47 \cdot 1$ & & ot reco & led & $54^{\circ} 0$ \\
\hline Bloemendal & 6 & $5^{2}$ & $I \cdot 84$ & $13 \cdot 2$ & $9^{2} \cdot 5$ & $5^{0}$ & $6 \cdot 08$ & 43.4 & $78 \cdot 0$ \\
\hline , & 7 & 4 & $5 \cdot 75$ & $4 I \cdot 2$ & $95^{\circ} 6$ & 50 & $8 \cdot 06$ & $57 \cdot 6$ & $93 \cdot 2$ \\
\hline , & 9 & $3^{8}$ & $2 \cdot 18$ & $15 \cdot 6$ & $86 \cdot 7$ & 50 & $8 \cdot 01$ & $5^{8 \cdot 1}$ & 93.5 \\
\hline , & 14 & 5 & $5 \cdot 40$ & $38 \cdot 6$ & $82 \cdot 0$ & 50 & $9 \cdot 16$ & 65.4 & $80 \cdot 9$ \\
\hline , & 15 & 260 & $4 \cdot 63$ & $33 \cdot I$ & $93 \cdot 5$ & 50 & $7 \cdot 30$ & $52 \cdot I$ & $92 \cdot 6$ \\
\hline , & 17 & 19 & $4 \cdot 26$ & $30 \cdot 4$ & $76 \cdot 4$ & 50 & $8 \cdot 90$ & 63.6 & $88 \cdot 0$ \\
\hline ," & 18 & II & $3 \cdot 00$ & $2 I \cdot 4$ & $95^{\circ} \mathrm{O}$ & $3^{1}$ & $7 \cdot 84$ & $54 \cdot 6$ & $96 \cdot 6$ \\
\hline , & 20 & 39 & $3 \cdot 20$ & $22 \cdot 9$ & $97^{\circ} 8$ & 50 & $9^{\cdot 24}$ & $66 \cdot 0$ & $95 \cdot 7$ \\
\hline , & 25 & 53 & $3 \cdot 83$ & $27 \cdot 4$ & $92 \cdot 6$ & 36 & $5 \cdot 00$ & $35 \cdot 7$ & $100 \cdot 0$ \\
\hline ," & 27 & 53 & $3 \cdot 57$ & $25 \cdot 5$ & $87 \cdot 4$ & 50 & $8 \cdot 42$ & $60 \cdot I$ & $93 \cdot 8$ \\
\hline ," & 32 & 10 & $4 \cdot 30$ & $30 \cdot 7$ & $88 \cdot 4$ & 50 & $6 \cdot 84$ & $48 \cdot 8$ & $90 \cdot 9$ \\
\hline \multirow{2}{*}{\multicolumn{2}{|c|}{, }} & 133 & $2 \cdot 69$ & $19 \cdot 2$ & $89 \cdot 7$ & 50 & $6 \cdot 62$ & $47 \cdot 3$ & 95.4 \\
\hline & & 1526 & $2 \cdot 72$ & 19.5 & $85 \cdot 3$ & 1027 & $6 \cdot 75$ & $48 \cdot 2$ & $86 \cdot 7$ \\
\hline
\end{tabular}

could it be determined with certainty that an ovule had not been lost in sectioning. Counts were also made of seeds and ovules in mature pods from 90 trees. Except in the case of one tree, the highest number of seeds, or seeds and undeveloped ovules together, in some 3500 pods examined was fourteen. The exception was tree No. 44, Bloemendal, in which out of 50 pods examined two with sixteen setds each were found.

It would seem, therefore, that the great majority of pods have a potential seed set of fourteen and that the occurrence of sixteen seeds in tree No. 44 was an unusual and individual characteristic of this tree. Consequently fourteen has been used in the calculation of fertility, which is based on the seed set as a percentage of this figure (table I). 
The three groups of trees, i.e. Sweetwaters, Yarrow and Mowbray, and Bloemendal differed significantly in their behaviour as regards both fertility and germination (fig.).

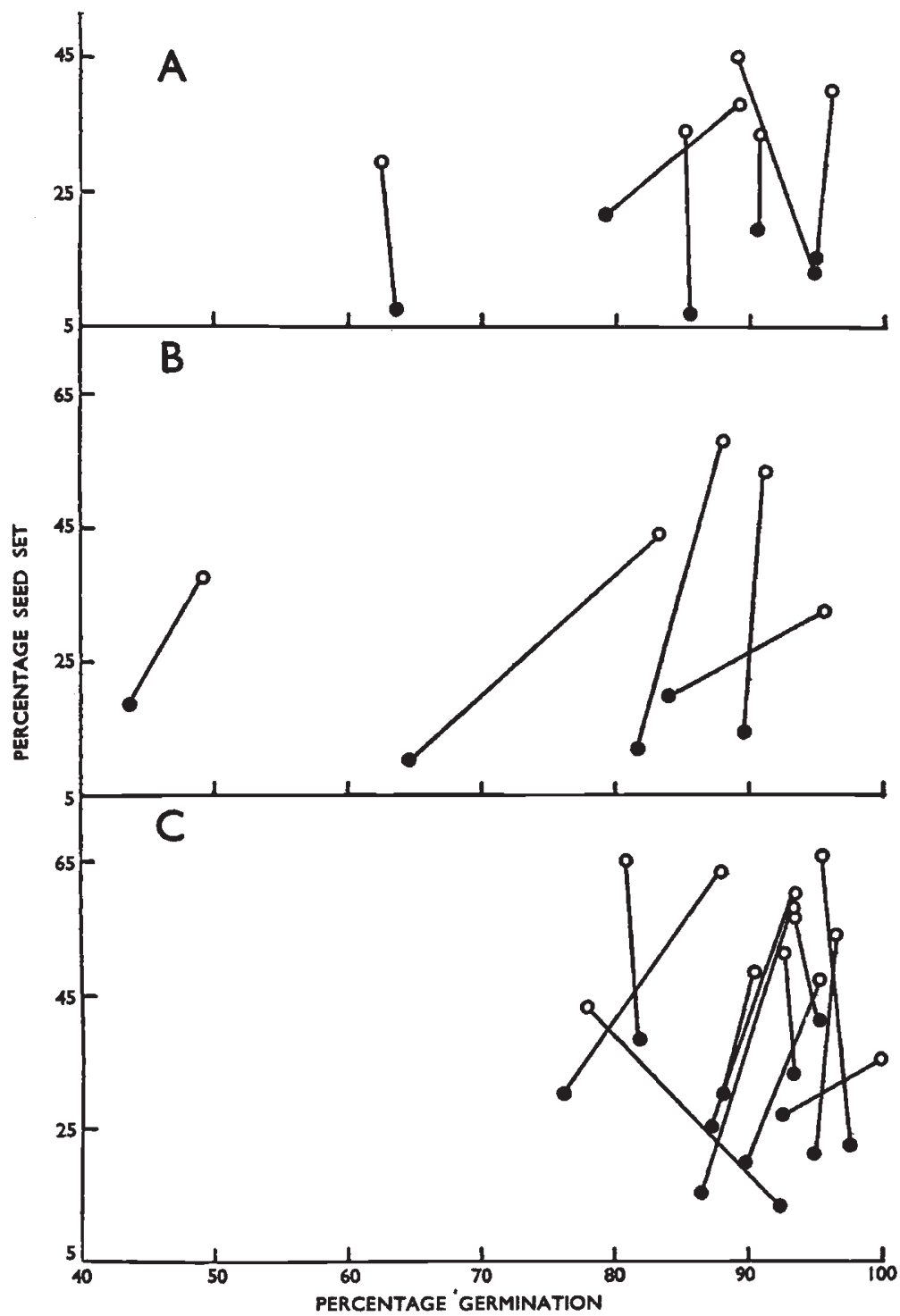

Fig.-Graph showing the relationship between seed set and germination following openpollination (open circles) and self-pollination (black circles) in individual trees of black wattle.

A. Sweetwaters group. B. Yarrow and Mowbray group. C. Bloemendal group.

In all groups, self-pollination resulted in a marked reduction in the mean number of seeds per pod. The possibility that this reduction was due, in part at least, either to an environmental effect induced by bagging or to inadequate pollination under the bag could not be entirely ruled out. Other observations, however, suggested that the 
reduction in fertility was not due to these causes, but was a real effect of self-pollination. When cross-pollinations were made under bags, heavy yields of pods and seeds resulted, while rubbing the inflorescence lightly with flowers from the same tree did not increase the yield of seed. In all three groups, there were significant differences between individual trees, but there was no correlation in the percentage seed set from self- and open-pollination on the same tree.

In the Sweetwaters trees there was no significant difference in germination between self- and open-pollinated seeds from the same tree, but differences between trees occurred. Trees from Bloemendal showed no difference in germinating capacity either between selfand open-pollinated seed from the same tree or between trees. In the Yarrow and Mowbray group, self-pollination brought about a significant $(P=0.01)$ decrease in percentage germination and trees also differed in over-all germinating ability. In all groups there was a positive correlation between the germination of selfed and natural seeds, indicating that germinating ability is a factor largely controlled by the parent tree.

The reasons for the differences between the groups was not clear. It may possibly have been due to strain differences, but in view of the small number of generations of wattle so far grown in South Africa and the free interchange of wattle seed between areas, this does not seem to be likely.

\section{SEGREGATION AND NATURAL CROSSING}

Of the twenty-six trees from which selfed progenies were grown, twenty-one segregated for one or more recessive characters. Families of open-pollinated seedlings were grown also and in every instance when the selfed family segregated for a recessive, the corresponding natural family segregated for the same character, but in a very different ratio. The degree of natural crossing in individual trees was calculated from the divergence in open-pollinated families from the ratio in which a character was shown to be segregating in the selfed family. Segregation of recessive seedling characters in both selfed and natural progenies and the calculated degree of natural crossing are shown in table 2.

\section{DESCRIPTION OF RECESSIVE CHARACTERS}

The cotyledons of black wattle seedlings are normally dark green, while the first seedling leaf is a deep bluish-green when fully expanded. Variation occurs among the blue-greens, some individuals being darker than others, but recessives are always distinct. The first seedling leaf following the cotyledons is unipinnate. Stems and undersides of the leaves are flushed red or purple with anthocyanin.

Albino. Albino seedlings had pale cotyledons and the first seedling leaf was white with a pink tinge. A few seedlings developed a trace of green but all died 
within three or four weeks of germination. There was a slight shortage of recessives which was homogeneous over all bagged branches $\chi^{2}{ }_{[5]}$ het. $=1 \cdot 103$.

Light-green. Light-green seedlings were paler than normal and lacked the typical "blueness".

Yellow-green. Yellow-green seedlings were paler than light-green and the seedling leaf had a definite yellowish cast. Segregation was clear-cut and scoring within

TABLE 2

Segregation of recessive characters and percentage natural crossing

\begin{tabular}{|c|c|c|c|c|c|c|c|c|}
\hline Tree number & \multirow{2}{*}{$\begin{array}{l}\text { Character paid } \\
\text { Blue-green, albino }\end{array}$} & \multicolumn{2}{|c|}{$\begin{array}{l}\text { Segregation } \\
\text { in selfed } \\
\text { families }\end{array}$} & \multirow{2}{*}{$\begin{array}{c}\begin{array}{c}\text { Ratio } \\
\text { assumed }\end{array} \\
3: I\end{array}$} & \multirow{2}{*}{$\begin{array}{c}\mathrm{P} \\
-.00 \\
\cdot 0-\cdot 05\end{array}$} & \multicolumn{2}{|c|}{$\begin{array}{l}\text { Segregation } \\
\text { in natural } \\
\text { families }\end{array}$} & \multirow{2}{*}{$\begin{array}{c}\begin{array}{c}\text { Minimum } \\
\text { natural } \\
\text { crossing } \\
\text { per cent. }\end{array} \\
86\end{array}$} \\
\hline Yarrow & & 206 & $5 I$ & & & 484 & 18 & \\
\hline Yarrow & $\begin{array}{l}\text { Blue-green, light } \\
\text { green }\end{array}$ & 23 & 9 & $3: 1$ & $.90-.80$ & 124 & 2 & 94 \\
\hline Yarrow & $\begin{array}{l}\text { Blue-green, yellow- } \\
\text { green }\end{array}$ & Io & II & $3: 1$ & $<\cdot 01$ & 275 & II & 85 \\
\hline Bloemendal 20 & $\begin{array}{l}\text { Blue-green, yellow- } \\
\text { green }\end{array}$ & 96 & 34 & $3: 1$ & $\cdot 90-80$ & $89 \mathrm{I}$ & $5^{I}$ & 78 \\
\hline Bloemendal i 7 & $\begin{array}{l}\text { Blue-green, yellow- } \\
\text { green }\end{array}$ & 62 & 6 & I5: I & $\cdot 70-\cdot 50$ & 794 & 12 & 76 \\
\hline Bloemendal 7 & Blue-green, yellow & 18 & 4 & $3: 1$ & $\cdot 70-50$ & Ior 5 & 36 & 86 \\
\hline Bloemendal 32 & Blue-green, yellow & 80 & 25 & $3: 1$ & $\cdot 70-\cdot 50$ & $\begin{array}{r}413 \\
* 1212\end{array}$ & $\begin{array}{r}32 \\
114\end{array}$ & $\begin{array}{l}71 \\
66\end{array}$ \\
\hline Bloemendal 32 & $\begin{array}{l}\text { Blue-green } \\
\text { variegated }\end{array}$ & 62 & 18 & $3: I$ & $\cdot 70-\cdot 50$ & $\begin{array}{r}396 \\
*_{1019}\end{array}$ & $\begin{array}{r}42 \\
193\end{array}$ & $\begin{array}{l}62 \\
36\end{array}$ \\
\hline Yarrow $\quad 53$ & Blue-green, blotchy & 12 & 9 & $3: I$ & $\cdot 20-\cdot 10$ & 273 & I3 & 82 \\
\hline Bloemendal i4 & Blue-green, blotchy & 27 & 5 & $3: 1$ & $\cdot 50-30$ & 804 & 5 & 97 \\
\hline Bloemendal 9 & Blue-green, blotchy & 47 & 14 & $3: I$ & $.90-.80$ & 908 & 20 & $9^{i}$ \\
\hline Ahrens $\quad 66$ & Blue-green, blotchy & 61 & 4 & $15: 1$ & $90-80$ & 468 & 5 & 83 \\
\hline Bloemendal i 5 & $\begin{array}{l}\text { Normal, withered } \\
\text { tips }\end{array}$ & 231 & 57 & $3: 1$ & $.05-.02$ & 974 & 29 & 88 \\
\hline Bloemendal 27 & $\begin{array}{l}\text { Normal, shed } \\
\text { pinnules }\end{array}$ & 77 & 33 & $3: 1$ & $\cdot 30-\cdot 20$ & 96 & I & 96 \\
\hline Sweetwaters I & $\begin{array}{l}\text { Normal, pointed } \\
\text { pinnules }\end{array}$ & 128 & 50 & $3: 1$ & $\cdot 50-30$ & 129 & 4 & 88 \\
\hline Sweetwaters & $\begin{array}{l}\text { Normal, pointed } \\
\text { pinnules }\end{array}$ & 104 & $26+7 ?$ & $3: 1$ & $\cdot 70-\cdot 50$ & 107 & 6 & 79 \\
\hline Sweetwaters 6 & $\begin{array}{l}\text { Normal, pointed } \\
\text { pinnules }\end{array}$ & 223 & $5^{1}$ & $3: 1$ & $\cdot 02-01$ & 129 & 9 & 74 \\
\hline Yarrow & $\begin{array}{l}\text { Normal, pointed } \\
\text { pinnules }\end{array}$ & $3 I$ & 9 & $3: 1$ & $\cdot 70-\cdot 50$ & 78 & 3 & 85 \\
\hline Bloemendal 9 & Normal, bipinnate & $\begin{array}{r}58 \\
256\end{array}$ & 6 & $\begin{array}{l}15: 1 \\
15: 1\end{array}$ & $\begin{array}{l}\cdot 50-30 \\
\cdot 20-\cdot 10\end{array}$ & $\begin{array}{r}89^{8} \\
1023\end{array}$ & $\begin{array}{l}5 \\
9\end{array}$ & $\begin{array}{l}91 \\
86\end{array}$ \\
\hline Bloemendal 34 & $\begin{array}{l}\text { Red stem, green } \\
\text { stem }\end{array}$ & $\begin{array}{r}25^{\circ} \\
5^{6}\end{array}$ & $\begin{array}{l}11 \\
17\end{array}$ & $\begin{array}{r}15: 1 \\
3: 1\end{array}$ & $.80-70$ & $9^{2}$ & 4 & 83 \\
\hline
\end{tabular}

* Second collection of natural seed.

each family easy, but comparison between families was difficult, partly because all the families segregating for yellow-green were not grown at the same time and partly because subtle differences, difficult to describe, occurred between families. Because of these differences it was thought to be unlikely that the same genes were concerned in all three families. Segregation in $15: 1$ as well as $3: 1$ ratios occurred.

In the family from Yarrow 53 the ratio of blue-green to yellow-green was outside the generally accepted limits of probability for a $3:$ r segregation, but gave a good fit with a $9: 7$ expectation. The numbers in the family were small, however, and for the moment it is best regarded as a monofactorial difference.

rellow. The yellow recessives in the families from trees Bloemendal No. 7 and 
No. 32 were very similar in appearance. These seedlings had yellowish cotyledons, but the seedling leaf, when it first unfolded, was scarcely distinguishable from normal. As the leaf grew older the colour changed rapidly to a clear yellow. Later leaves behaved in a similar manner and seedlings showing the character were much retarded in growth.

Pale yellow. In the open-pollinated families from both tree No. 7 and tree No. 32 a type segregated which had not occurred in the selfed progeny. Three seedlings out of 1015 from tree No. 7 and four out of 1428 from tree No. 32 had normal green cotyledons, but a very pale yellow first seedling leaf. As the leaf matured it gradually turned green until at the end of a few days it was scarcely distinguishable from normal except for a somewhat slaty appearance.

Although this character appeared in open-pollinated progeny only, some estimate of the ratio in which it was segregating may be made. In the selfed families from these two trees yellow behaved as a simple recessive. From the number of yellow recessives in the open-pollinated families it is possible to place the total number of selfed seedlings in each family as approximately 144 and 584 respectively. Assuming a $63: 1$ segregation of pale-yellow to other selfed seedlings the ratio is within the 0.05 per cent. limit of probability in both families and when the families are added together the ratio fits fairly well with expectation $(P=0.20-0 \cdot 10)$. The non-appearance of pale-yellows in selfed families can be explained purely on the grounds of insufficient numbers.

Variegated. This character was detected in the first seedling leaf, but showed up more clearly in the second to fourth leaves. The expression varied considerably and when patches of white were large, some deformation of the leaf occurred due, presumably, to unequal growth between green and white areas.

Blotchy. Phenotypically, blotchy appeared to be the same character in all four families in which it segregated. Small brown spots appeared on the first seedling leaf, but it was not until four or five leaves had expanded that the character reached its full expression. As the leaves unfolded the ends of the pinnæ curled under, the leaf became paler, and the leaf surface developed numerous irregular brown blotches. Blotchy seedlings were markedly less vigorous than normal seedlings. The character segregated in both $3: 1$ and $15: 1$ ratios.

Withered tips. Tips of the pinnules, which were slightly more pointed than usual, died back to a depth of about one millimetre. Seedlings were stunted and weakly and many died in the nursery. Assuming the character to be monofactorial, there was a shortage of recessives which was homogeneous over all eleven bagged branches which made up the family $\left(\chi^{2}[10]\right.$ het. $\left.11 \cdot 407\right)$.

Shed pinnules. In this type the first seedling leaf was small and almost colourless with the pinnules curled and bunched together. Subsequently, the pinnules fell off without having expanded, leaving the bare midrib of the first leaf. A number of seedlings produced second and third leaves which were greatly reduced in size and of a pale pink colour. These leaves did not shed their pinnules. None of the seedlings survived more than a few weeks.

Pointed pinnules. The pointed pinnule character did not become obvious until seedlings had formed some four or five leaves. Pinnules which were more widely spaced than usual tapered rapidly to a point in contrast to the normal rounded ends. In the family from Sweetwaters No. 6 there was a significant shortage of the recessive type which was consistent over all bagged branches $\left(\chi^{2}[11]\right.$ het. 1.658).

Bipinnate. The bipinnate character appeared as subdivision, to a greater or lesser degree, of the pinnules of the normally unipinnate first leaf. The expression of the character was very variable. At one extreme all the pinnules of the first leaf were sub-divided to give a completely bipinnate leaf, while at the other extreme only a few small subdivisions on a single pinnule occurred. Intermediates between these extremes were most frequent, one or two pinnules being fully sub-divided while the rest of the pinnules remained entire. Subsequently, it has been found that the factors responsible for bipinnate first seedling leaf also affected mature leaves. a few pinnules being fully or partially sub-divided. Mature leaves showing 
this character are, therefore, partially tripinnate. At least two genes are responsible for this character.

Green stem. Green stem recessives appeared to be completely free from anthycyanin on the stem in contrast to the normal reddish colouration.

\section{TWO-FACTOR RATIOS AND LINKAGE}

Families from four trees segregated for two recessive seedling characters in each (table 3 ).

There was some indication of linkage between yellow-green and blotchy in the selfed progeny from Yarrow No. 53, but because of

TABLE 3

Two-factor segregation of seedling characters

\begin{tabular}{|c|c|c|c|c|c|}
\hline Tree number & $\begin{array}{c}\text { Blue-green } \\
\text { normal }\end{array}$ & $\begin{array}{l}\text { Blue-green } \\
\text { blotchy }\end{array}$ & $\begin{array}{c}\text { Yellow-green } \\
\text { normal }\end{array}$ & $\begin{array}{c}\text { Yellow-green } \\
\text { blotchy }\end{array}$ & $\mathbf{P}$ \\
\hline $\begin{array}{l}\text { Yarrow } 53 \\
\text { Exp. 9:3:3:1 }\end{array}$ & $\begin{array}{l}8 \\
11 \cdot 7\end{array}$ & $\begin{array}{l}2 \\
3 \cdot 9\end{array}$ & $\begin{array}{l}4 \\
3 \cdot 9\end{array}$ & $\begin{array}{l}7 \\
1 \cdot 3\end{array}$ & $<0.01$ \\
\hline $\begin{array}{l}\text { Bloemendal } 32 \\
\text { Exp. 9:3:4 }\end{array}$ & $\begin{array}{c}\text { Blue-green } \\
\text { normal } \\
61 \\
5^{8 \cdot 5}\end{array}$ & $\begin{array}{c}\text { Blue-green } \\
\text { variegated } \\
18 \\
19.5\end{array}$ & $\begin{array}{c}\text { Yellow-green } \\
25 \\
26 \cdot 0\end{array}$ & $\begin{array}{l}\cdots \\
\cdots\end{array}$ & $0.95-0.90$ \\
\hline $\begin{array}{l}\text { Bloemendal } 27 \\
\text { Exp. 9:3:4 }\end{array}$ & $\begin{array}{c}\text { Normal } \\
\text { normal } \\
60 \\
6 \mathrm{I} \cdot 2\end{array}$ & $\begin{array}{l}\text { Normal } \\
\text { green stem } \\
\text { I } 7 \\
20.4\end{array}$ & $\begin{array}{c}\text { Shed } \\
\text { pinnules } \\
33 \\
27^{\cdot} \cdot 2\end{array}$ & $\begin{array}{l}\cdots \\
\cdots\end{array}$ & $0.50-0.30$ \\
\hline $\begin{array}{l}\text { Bloemendal } 9 \\
\text { Exp. } 45: 15: 3: 1\end{array}$ & $\begin{array}{c}\text { Normal } \\
\text { unipinnate } \\
\quad 4^{2} \\
43^{\cdot} \cdot 6\end{array}$ & $\begin{array}{l}\text { Blotchy } \\
\text { unipinnate } \\
\text { 14 } \\
\text { 14.5 }\end{array}$ & $\begin{array}{c}\text { Normal } \\
\text { bipinnate } \\
5 \\
2 \cdot 9\end{array}$ & $\begin{array}{l}\text { Blotchy } \\
\text { bipinnate } \\
\text { I } \\
\text { I }\end{array}$ & $0.50-0.30$ \\
\hline
\end{tabular}

the low numbers in the family and the abnormal single factor segregation of yellow-green, the confirmation or otherwise of linkage must await the collection of further data.

In the other three trees, the two-factor ratios gave good agreement with expectation on independent assortment. Yellow was epistatic to variegated and shed pinnules to green-stem, resulting in $9: 3: 4$ segregations. In tree No. 9, blotchy segregated as $3:$ I and bipinnate as $15:$ I ratio giving two-factor expectation of $45:$ I5:3:1, with which there was good agreement.

In four families there was strong evidence of linkage between pointed pinnules and a second character which appeared at a later stage in development, namely dwarf habit. The parents of three of these families, i.e. Sweetwaters Nos. I, 2, and 6, were open-pollinated seedlings from the same parent tree. It is not known whether these three are related to the fourth tree, Yarrow No. 52. Two-factor 
segregations of pointed pinnules and dwarf habit are given in table 4 .

Single-factor ratios were upset by a higher mortality of pointed pinnule than normal seedlings; analysis of the data showed that when homozygous, the pointed pinnule gene depresses viability by about 50 per cent., but there was no evidence of the dwarf gene depressing viability. There was no evidence of differential germination among the genetic classes.

The four families were homogeneous for recombination value and so may be grouped together. Taking the four families, the recombination value was $8.7 \pm 0.94$ per cent. Since the recombination classes are poorly represented in some families, this value must be accepted with caution. It can, however, be said with some confidence that the genes pointed pinnules and dwarf habit are linked with rather less than ro per cent. recombination.

TABLE 4

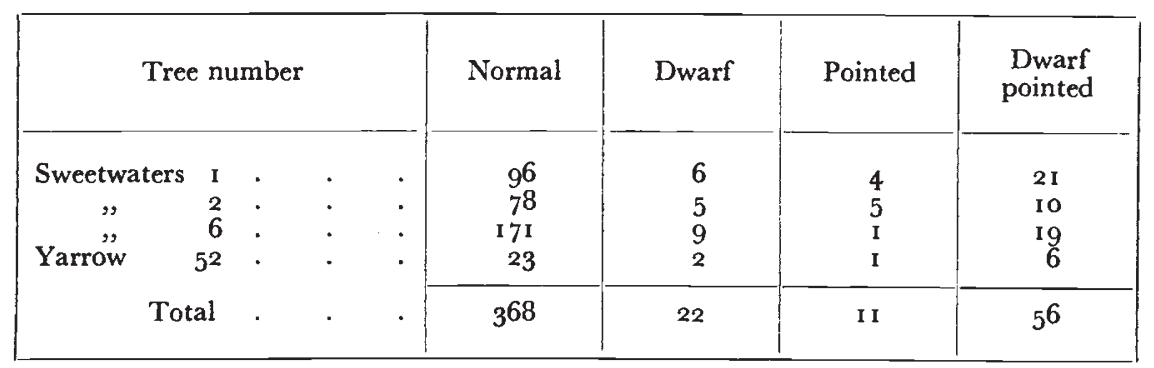

\section{NATURAL CROSSING}

The percentage natural crossing which occurs with each of the trees was calculated on the assumption that all foreign pollen which effected fertilisation carried dominant genes in respect of the seedling characters for which the trees were heterozygous. The figure is, therefore, the minimum percentage natural crossing and takes no account of foreign pollen carrying the same recessive gene, a factor which may be of some importance in wattle. The calculated natural crossing is given in the last column of table 2.

In most trees, when more than one recessive character segregated, the natural crossing calculated from the segregation of each character in the open-pollinated families showed fairly good agreement. From Bloemendal No. 32, however, a second collection of seed gave anomalous results for one character. This tree segregated for two recessives, namely yellow and variegated, both of which gave good $3:$ I ratios in the selfed family.

From the first collection of open-pollinated seed, the numbers of normal to yellow and normal to variegated were $4^{1} 3: 3^{2}$ and $396: 4^{2}$ respectively. As expected, the ratio of normal to recessives shows good agreement for both characters $\left(\chi_{[1]}^{2}=0.903\right)$. When the 
proportion of normals to yellows in the first and second collections of seed is compared there is also good agreement, the figures being 413:32 and I 2 I $2:$ I I 4 respectively $\left(\chi_{[1]}^{2}=0.873\right)$. When, however, the number of yellows and variegated in the second coliection are compared, there is wide divergence from the expected ratios, the figures being I 2 I2 normal to II 4 yellow and IoI9 normal to I93 variegated $\left(\chi_{[1]}^{2}=31 \cdot 972\right)$. Similarly, there is a significant difference in the proportion of variegated to normal occurring in the first collection of seed and that of variegated to normal in the second collection. It is evident that variegated is segregating in different ratio from yellow in the second collection of seed and from both yellow and variegated in the first collection.

The most likely explanation of this discrepancy is that a neighbouring tree to No. 32, also carrying the gene for variegation, had come into flower or the flowering time had coincided with No. $3^{2}$ in the second year, and that a number of the variegated recessives were, in fact, due to foreign pollen carrying the same recessive genes.

\section{DISCUSSION}

The estimated mean percentage natural crossing in black wattle is of very much the same order as that in green wattle, being 84 and 85 per cent. respectively. Osborn (I93I) gives counts of recessive seedling characters appearing in ten trees and, grouping the ten trees together, the total of normal to recessives was 23750:869. Assuming that the characters are all behaving as simple recessives, this gives a natural crossing of 86 per cent., again showing close agreement.

It may be taken, therefore, that the mean minimum percentage crossing is in the neighbourhood of 85 per cent. In both species, there is wide variation between individual trees, the degree of crosspollination ranging from 35 to roo per cent. in green wattle (Philp and Sherry) and from 62 to 97 per cent. in black wattle. This range of variation may be connected with differences in self-fertility such as have been shown to occur, but on the somewhat scanty data available, there is no indication of any correlation between self-fertility and cross-pollination.

Another possibility is that the apparent low degree of crosspollination in some trees is due to neighbouring trees carrying the same recessive gene so that self- and cross-pollination are not completely distinguishable. Since wattle seed is heavy and is not dispersed over any great distance from the parent tree, the method of re-establishment by natural regeneration adopted in the majority of wattle plantations lends itself to the formation of groups of trees having recessive genes in common. Bateman (1947) has derived evidence from his studies of both insect- and wind-pollinated crops which suggests that if seed were not widely distributed from the parent tree, there would be a correlation between proximity and closeness of relationship.

It is possible, therefore, that the assumption made when calculating 
the degree of natural cross-pollination, i.e. that all foreign pollen effecting fertilisation carries a dominant in respect of the gene on which the calculations are based, may lead to considerable errors. A case in point is the anomaly encountered in tree Bloemendal No. 32. If the degree of natural cross-pollination in this tree were based on the segregation of the variegated recessive in the second collection of seed only, the calculated figure would be 36 per cent., whereas calculated from the segregation of the yellow recessive in both collections of seed or variegated in the first, the degree of natural crossing would be in the neighbourhood of 67 per cent. It is possible, therefore, that the percentage cross-pollination in wattle is considerably higher, in some instances at least, than that calculated from ratios of normal to recessives in natural seed.

Variation. Where there is a high degree of cross-pollination, the general breeding behaviour of a population may be predicted with considerable accuracy. It is characteristic of such populations that they exhibit variability and that the intermediate phenotypes are favoured at the expense of the extremes (Darlington and Mather, 1949). Because of the flow of variability maintained by outcrossing, extreme types are not lost to the population, but constantly reappear by segregation. Any alteration, whether natural or artificial, in the selective force, will favour more extreme types and cause the average to shift to meet the new conditions. Similarly, interference with the outbreeding mechanism will break down the relational balance established by natural selection and cause a new, and probably less efficient, balance to be set up.

As is to be expected from the high percentage natural crossing, both green and black wattles conform closely to this pattern. All characters examined, including tannin content of the bark, showed wide variation, with the majority of individuals close to the mean. Some of this variation is undoubtedly due to environment, but from the results of progeny trials, it is concluded that much of the variation must be explained on a genetic basis. Families consisting of the open-pollinated progeny from individual trees differ significantly from each other in vigour and also show striking differences in morphological characters such as stem form, branching habit, foliage, etc. From an economic point of view, some of these families are better than average, others are poorer. Under natural conditions, the progeny of both extremes will be pulled back towards the average, but with artificial selection for the economically more advantageous characters, it should be possible to shift the average closer to the desired type.

Again, forced inbreeding has the expected effect. Self-pollination in wattle uncovers numerous recessive genes, the great majority of which are deleterious to a greater or lesser extent when homozygous. At the same time, the relational balance built up by natural selection is broken down and a new and less efficient balance forced upon the 
plant. The result of this new balance is the typical inbreeding depression in vigour shown by the progeny of both green and black wattles when the trees are self-pollinated (Anon., 1953).

It is evident that the breeding behaviour of the black wattle closely resembles that of green wattle and that both must be regarded as typically outcrossing species. Philp and Sherry (1946) have discussed in some detail the effect of the pollination mechanism on the formulation of a wattle-breeding programme and it is unnecessary to reiterate their conclusions here.

\section{SUMMARY}

I. In twenty-six trees of black wattle studied, the percentage seed set on self-pollination was consistently lower than that from openpollination.

2. The progeny of twenty-one of the trees segregated for recessive characters in both selfed and open-pollinated families. From the divergence from expectation of the ratios of dominant to recessives in open-pollinated families, the approximate degree of natural crossing was calculated.

3. Cross-pollination ranged from $62-97$ per cent. with a mean of 84 per cent. and in this respect black wattle was very similar to green wattle.

4. Linkage between two characters, pointed pinnules and dwarf habit, was found in four families the recombination value being approximately 8.7 per cent.

Acknowledgments.-I am indebted to Professor K. Mather for reading through the original draft of the paper and for making helpful suggestions, and to Miss K. Nixon for assistance with scoring the families.

\section{REFERENCES}

ANON. I953. Rep. Wattle Res. Inst. for 1952-53.

DARLington, c. D., AND MATHER, K. I949. The Elements of Genetics. London, Allen \& Unwin.

bateman, A. J. I947. Contamination in seed crops. III. Relation with isolation distance. Heredity, $I$, 303-306.

osborn, J. B. 1931. Seed selection in black wattle (Acacia mollissima). Emp. For. F., 10, 190-202.

PHILP, J., AND SHERRY, s. P. I946. The degree of natural crossing in green wattle, Acacia decurrens Willd., and its bearing on wattle breeding. F. S. Afr. For. Ass., I4, I-28. 